\title{
DAYAN (Daniel), KATZ (Elihu), La Télévision cérémonielle
}

Paris, Presses Universitaires de France, 1996, 259 p. (trad, de I'anglais par Daniel Dayan, préf. de Lucien Sfez) (bibliogr.) (coll. « La Politique Éclatée »)

Grace Davie

\section{OpenEdition}

1 Journals

Electronic version

URL: http://journals.openedition.org/assr/20627

DOI: 10.4000/assr.20627

ISSN: $1777-5825$

Publisher

Éditions de l'EHESS

Printed version

Date of publication: 1 July 2000

Number of pages: 113-114

ISBN: 2-222-96691-4

ISSN: 0335-5985

Electronic reference

Grace Davie, «DAYAN (Daniel), KATZ (Elihu), La Télévision cérémonielle », Archives de sciences sociales des religions [Online], 110 | avril-juin 2000, document 110-57, Online since 19 August 2009, connection on 21 September 2020. URL : http://journals.openedition.org/assr/20627 ; DOI : https://doi.org/ 10.4000 /assr.20627

This text was automatically generated on 21 September 2020

(c) Archives de sciences sociales des religions 


\section{DAYAN (Daniel), KATZ (Elihu), La Télévision cérémonielle}

Paris, Presses Universitaires de France, 1996, 259 p. (trad, de I'anglais par Daniel Dayan, préf. de Lucien Sfez) (bibliogr.) (coll. « La Politique Éclatée »)

\section{Grace Davie}

\section{REFERENCES}

DAYAN (Daniel), KATZ (Elihu), La Télévision cérémonielle, Paris, Presses Universitaires de France, 1996, 259 p. (trad, de l'anglais par Daniel Dayan, préf. de Lucien Sfez) (bibliogr.) (coll. « La Politique Éclatée »)

1 La Television cérémonielle was first published by Harvard University Press in 1992; the 1996 edition presents the same material to a primarily French, but also an European audience. As a British reviewer I find myself caught between the two cultures. Englishspeaking sociologists are accustomed to reading American material without, in many cases, paying sufficient attention to the difference between Europe and the United States. Reading the book in French brought me up short, not least in acknowledging the public/private distinctions which are notably different in the old world and the new. Europeans sustain a more private culture that Americans whose predilection for watching television with someone (le "voir avec") is notably more developed than in Europe.

2 A second factor concerns the time-lag between the two editions and the changing nature of media events. The majority of the examples chosen are drawn from the mid post-war decades. Whilst some of these continue to resonate "as if they were yesterday" (in some respects a feature of media events), others do not and just occasionally give the text a dated feel.

3 Having said this, I found the analysis itself both enduring and stimulating, equally applicable to more recent happenings (not least to the millennium itself). Media events 
are divided into three types: contests (political or sporting), conquests (when norms are overridden by "larger than life" individuals) and coronations (characterised primarily by ceremonial and often associated with royalty). Each of these is legitimated by a different type of authority, taken from the familiar Weberian distinctions between rational-legal (contests), charismatic (conquests) and traditional (coronations). Having established the typology, the authors take the reader through the various "stages" of a media event: its initial negotiation, its "performance", the response of the public, the actions it is likely to provoke or to permit, and its effects and consequences.

The implications for the sociologist of religion are considerable and operate at many levels. In the first place media events provoke questions within the churches themselves as different or conflicting interpretations are hugely magnified. More radical, however, is the blurring of the line between the sacred and the profane, as (a) religious events are no longer isolated from the norms and values of the secular world, not least those of the political realm and (b) political or civil events acquire an aura of the sacred. Anyone, finally, who is interested in ritual and the possibility of vicarious participation in ritual events through television would do well to read this book (the theological implications are considerable).

The confusions and cross-overs between religion and politics are well-exemplified in the personality and role of the present Pope, John-Paul II. Unsurprisingly, he becomes a major figure in the analysis as a whole, not least as a travelling pontiff (invariably accompanied by the media circus), but more specifically in his role in the annus mirabilis of 1989. The significance of television in the dramatic unfolding of events in Central Europe remains as fresh today as when the events first happened. As I read, I recalled a vivid account of a Czech colleague whose family were torn between demonstrating themselves on the streets of a provincial city in the then Czechoslovakia or staying at home and taking part through television in the primary narrative that was unfolding in Prague.

Much is made, finally, of the British royal family and their role as media personalities. The marriage of Charles and Diana provides a major example. The framework presented in La Télévision cérémonielle now lends itself to a detailed analysis of Diana's funeral - interesting precisely because of its ambiguous place in royal events. Was divorced Diana royal or was she not? And did the funeral and its amplification through the media capture or confuse this ambiguity? Whatever the case, the funeral itself was a truly global event watched live by an audience numbered in billions. But in another sense it was simply a family funeral taking place in the state church of a Northern European nation. In the last analysis it was thechurch, not the media, that provided the liturgy to mark the ending of Diana's life - just as it does for every other citizen who requests such a service. 